\title{
DOSE-DEPENDENCE OF SUPEROVULATION RESPONSE IN MICE TO TWO INJECTIONS OF PMSG
}

\author{
C. M. GHRISTENSON AND B. E. ELEFTHERIOU \\ The Fackson Laboratory, Bar Harbor, Maine, 04609, U.S.A. \\ (Received 18th Fanuary 1971, accepted 29th December 1971)
}

\begin{abstract}
Summary. Female C57BL/6J mice were injected on Day 24 of age with one of the following doses of PMSG: 1, 2, 4, 8, 16 or 24 i.u., and again on Day 26 with an identical dose. More than $85 \%$ of the variation of the number of ova produced between doses 1 and 16 is accounted for by its corresponding variation in dose. At 24 i.u. of PMSG, the response declined significantly. This phenomenon indicates that PMSG, an FSH-like substance, not only provides for follicular maturation but also can cause release of ova without the synergistic effect of HGG, an LH-like substance, perhaps through stimulation of the release of endogenous LH.
\end{abstract}

Studies of the induction of superovulation by exogenous gonadotrophins have been made in various rodents (Rowlands \& Parkes, 1966). Generally, it has been accepted that pregnant mare's serum gonadotrophin (PMSG) acts to stimulate follicular growth, preparing the follicles for ovulation, thus mimicking the endogenous follicle-stimulating hormone (FSH), while the subsequent human chorionic gonadotrophin (HCG) acts like the luteinizing hormone (LH), to stimulate the release of ova from the matured follicles. However, HCG injection is unnecessary for the release of ova from properly primed follicles (Zarrow \& Quinn, 1963). The present study demonstrates that superovulation can be induced by the use of two injections of PMSG, and that the response is dose dependent.

One hundred and twenty G57BL/6J female mice, with body weights of 13.5 to $16.4 \mathrm{~g}$ at autopsy, were housed five to a cage following weaning at 21 days of age. Lighting was kept on a $12 / 12 \mathrm{hr}$ schedule (on at 06.00 hours off at 18.00 hours). At 09.00 hours on Day 24 after birth, each mouse was injected subcutaneously with PMSG (Ayerst-Equinex). The PMSG was given in one of the following doses: $1,2,4,8,16$ or 24 i.u. in $0.1 \mathrm{ml}$ of $0.85 \%$ saline. Forty-eight hours later, at 09.00 hours on the 26th day, each animal was given a second injection of PMSG identical to that which it had received previously. The mice were killed by cervical dislocation $24 \mathrm{hr}$ after the final injection. Ova were counted under a $\times 40$ dissecting binocular microscope (Zarrow, Caldwell, Hafez \& Pincus, 1958). Statistical analysis was by unweighted linear regression.

The results are summarized in Table 1 . Two consecutive doses of 1 i.u. PMSG resulted in an average count of 9.2 ova/animal. When the dose level was doubled, the number of ova/animal doubled although the proportion of ova count increase was not always directly proportional to the dose of PMSG when 
the latter was subsequently increased. When doses were increased to $24 \mathrm{i}$.u. each, a sharp decline in the number of ova occurred, and a few animals failed to ovulate. Failure of individuals to ovulate in response to two injections of PMSG did not occur at any lower dose level. The ova count following double injections of 24 i.u. was lower than that following two injections of 1 i.u. Histological examination showed that this was primarily due to premature luteinization of follicles and not therefore to block of endogenous release of gonadotrophin. Variances within groups at each dose level were very low, but generally variance increased as the dose level increased.

TABLE 1

AVERAGE NUMBER OF OVA SHED BY IMMATURE MICE IN RESPONSE TO PMSG

\begin{tabular}{|c|c|c|c|c|c|}
\hline \multicolumn{3}{|c|}{$\begin{array}{l}\text { Doses of } P M S G \\
\text { in i.u. }\end{array}$} & \multirow{2}{*}{$\begin{array}{l}\text { No. of } \\
\text { animals }\end{array}$} & \multirow{2}{*}{$\begin{array}{l}\text { Mean no. of } \\
\text { ova } \pm \text { S.E. }\end{array}$} & \multirow{2}{*}{$\begin{array}{c}\% \\
\text { ovulating }\end{array}$} \\
\hline Day 24* & 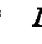 & Day 26* & & & \\
\hline 0 & + & 1 & 18 & 0 & - \\
\hline 0 & + & 2 & 18 & 0 & 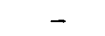 \\
\hline 0 & + & 4 & 18 & $3 \cdot 2 \pm 0 \cdot 27$ & 33 \\
\hline 0 & + & 8 & 18 & $4.8 \pm 0.62$ & 72 \\
\hline 0 & + & 16 & 18 & $7 \cdot 2 \pm 0.80$ & 100 \\
\hline 0 & + & 24 & 18 & $10 \cdot 3 \pm 0.62$ & 100 \\
\hline 1 & + & 1 & 20 & $9.15 \pm 0.25$ & 100 \\
\hline 2 & + & 2 & 20 & $18.8 \pm 0.87$ & 100 \\
\hline 4 & + & 4 & 20 & $36.5 \pm 1.29$ & 100 \\
\hline 8 & + & 8 & 20 & $67 \cdot 3 \pm 1 \cdot 88$ & 100 \\
\hline 16 & + & 16 & 20 & $84 \cdot 4 \pm 2 \cdot 70$ & 100 \\
\hline 24 & + & 24 & 24 & $7 \cdot 8 \pm 1.54$ & 90 \\
\hline
\end{tabular}

Time of autopsy: $72 \mathrm{hr}$ after initial PMsg injection. * After birth.

In most laboratory experiments, superovulation is induced by exogenous HGG which is considered to possess LH-like activity. The suggestion has been made (Lostroh \& Johnson, 1966) that both FSH and LH were necessary for the maturation of follicles, but that either FsH or LH alone could cause rupture and release of ova. Ovulation has been produced in hypophysectomized rats by two injections of PMSG (Rowlands \& Williams, 1943), but the percentage of animals which ovulated was low and the number of ova released was also low, certainly below that revealed by our findings. Furthermore, the earlier preparations of PMSG (Rowlands \& Williams, 1943) were contaminated by LH-like substances to a greater degree than later preparations used by us and other investigators (Zarrow \& Quinn, 1963). Ovulation has also been induced by injecting FSH only into PMSG-primed rats (Goldman \& Mahesh, 1968). Thus, FsH may be necessary for the release as well as the development of follicles. Although the present data differ significantly from that of Stern \& Schuetz (1970), it must be kept in mind that these investigators used a different strain of mice and also used 6- to 8-week-old animals.

It is possible that enough endogenous hypophysial LH was supplied to act synergistically with the PMSG to stimulate the maturation process or the release 
of the ova. This might be due to a feed-back effect upon the pituitary from steroids released by the developing follicles. Oestrogenic stimulation is known to deplete pituitary gonadotrophin levels, especially of FSH (Corbin \& Daniels, 1969).

A direct feed-back effect from the second injection of PMSG upon the control system which regulates FSH-LH synthesis and release might also be implicated. When HCG was used in our laboratory to produce superovulation in PMSG-primed animals, a large proportion of the ova were found to be denuded, indicating that ovulation had occurred shortly after the injection of HGG. However, with PMSG used in the second step, most ova were surrounded by cumulus cells, indicating more recent ovulation and, thus, the possible synchronization with, or facilitation of, endogenous gonadotrophin (LH) release by the second injection of PMSG. Superovulation following a single injection of PMSG (Table 1) did not occur, nor did it occur in our previous experiment following a single injection of 1, 3, 5 or 7 i.u. PMSG (Zarrow, Christenson, \& Eleftheriou, 1971).

Thus, we have shown that double injections of PMSG can cause both follicular development and release of ova in immature mice and, further, that the number of ova produced and released is dose-dependent.

This research was supported in part by an allocation from General Research Support Grant FR 05545 from the Division of Research Resources to The Jackson Laboratory and in part by NIH Training Grant CA 05013 from the National Cancer Institute.

\section{REFERENCES}

Conbin, A. \& Daniels, E. L. (1969) Induction of puberty in immature female rats. Effect of estrogen on pituitary FSH and stalk-median-eminence FsH-releasing factor. Neuroendocrinology, 4, 65.

Goldman, B. D. \& MAHESH, V.B. (1968) Fluctuations in pituitary FSH during the ovulatory cycle in the rat and the possible role of FSH in the induction of ovulation. Endocrinology, 83, 97.

Lostroh, A. J. \& Johnson, R. (1966) Amounts of interstitial cell-stimulating hormone and folliclestimulating hormone required for follicular development, uterine growth and ovulation in the hypophysectomized rat. Endocrinology, 79, 991.

Rowlands, I. W. \& PARKes, A. S. (1966) Hypophysectomy and the gonadotrophins. In: Marshall's Physiology of Reproduction, 3rd edn, Vol. III, p. 26. Ed. A. S. Parkes. Longmans, London.

Rowlands, I. W. \& Williams, P. C. (1943) Production of ovulation in hypophysectomized rats. $\mathcal{F}$. Endocr. 3, 310.

Stern, S. \& Schuetz, A. W. (1970) Asynchrony of ovulation and mating in mice treated with gonadotrophins. 7. Reprod. Fert. 23, 257.

Zarrow, M. X., Galdwell, A. L., Jr, Hafez, E. S. E. \& Pincus, G. (1958) Superovulation in the immature rat as a possible assay for LH and HCG. Endocrinology, 63, 748.

Zarrow, M. X., Christenson, G. M. \& Elefrtheriov, B. E. (1971) The effect of various doses of PMs in pheromonal facilitation of ovulation in two strains of mice. Biol. Reprod. 4, 52.

ZArrow, M. X. \& QuinN, D. L. (1963) Superovulation in the immature rat following treatment with PMS alone and inhibition of PMs-induced ovulation. F. Endocr. 26, 181. 